\title{
ПЕДАГОГИЧЕСКИЕ УСЛОВИЯ ФОРМИРОВАНИЯ КОММУНИКАТИВНОЙ КОМПЕТЕНЦИИ СТУДЕНТОВ-БИЛИНГВОВ В ТЕХНИЧЕСКОМ ВУЗЕ
}

\section{PEDAGOGICAL CONDITIONS \\ OF COMMUNICATIVE COMPETENCE FORMATION OF BILINGUAL STUDENTS OF A TECHNICAL UNIVERSITY}

\section{S. Zarovniaeva \\ T. Shagdarova \\ I. Malanov}

Summary: The article considers the concept of "communicative competence" as a fundamental component of readiness for education and self-development of a person. Particular attention is paid to the formation of foreign-language professional communicative competence of students of a technical university in a multilingual condition. To determine the communicative competence, the authors tested "Self-assessment of the communicative competence", which allows for systematic monitoring of the level of communicative competence. As a result of the diagnosis, it was revealed that most students are characterized by medium or medium with a tendency to low levels of communicative competence.

Keywords: communicative competence, pedagogical conditions, bilingual students, foreign professional communication, personal and ethnic characteristics, motivation, pedagogical technologies.

\section{Введение}

$\mathrm{B}$ век глобализации и интеграции мировых научных и технических сообществ большое внимание уделяется повышению уровня образования и компетентности будущих специалистов технических вузов.

Выпускник должен обладать не только профессиональными компетенциями, но и определенными коммуникативно-речевыми навыками (способностью к деловой коммуникации на государственном и иностранном языках (УК-4), проявляющейся в умении применять на практике полученные знания в устной и письменной формах) [1].

В условиях активного многоязычия и диалога культур, владение иностранным языком является определяющим звеном формирования конкурентоспособной
Заровняева Сильвия Сергеевна

Старший преподаватель, Политехнический институт (филиал) ФГАОУ ВО «Северо-Восточный федеральный университет им. М.К. Аммосова» в г. Мирном silka86@mail.ru

Шагдарова Туяна Владимировна Стариий преподаватель, Политехнический институт (филиал) ФГАОУ ВО «Северо-Восточный федеральный университет им. М.К. Аммосова» в г. Мирном tuyanash.21@mail.ru

Маланов Иннокентий Александрович Д.п.н., профессор, ФГБОУ ВО «Бурятский государственный университет имени Доржи Банзарова» (2. Улан-Удэ) malanov52@mail.ru

Аннотация: В статье рассматривается понятие «коммуникативная компетенция» как основополагающий компонент готовности к образованию и саморазвитию личности. Особое внимание уделяется формированию иноязычной профессиональной коммуникативной компетенции студентов технического вуза в условиях многоязычия. Для определения коммуникативной компетентности студентов-билингвов, авторами было проведено тестирование «Самооценка коммуникативной компетентности обучающихся», которое позволяет осуществлять системный мониторинг уровня коммуникативной компетентности. Результаты психодиагностики, показали, что основная часть респондентов обладает средним или средним с тенденцией к низкому уровнем коммуникативной компетентности.

Ключевые слова: коммуникативная компетенция, педагогические условия, студенты-билингвы, иноязычная профессиональная коммуникация, личностные и этнические особенности, мотивация, педагогические технологии.

личности будущего специалиста. В этой связи одной из первостепенной задачей обучения является формирование у него коммуникативной компетенции как интегративного свойства личности, обеспечивающего успешность действия в различных иноязычных профессиональных речевых ситуациях.

Известно, что трудовая деятельность выпускника технического вуза не может осуществляться вне его профессиональной речевой культуры. Однако, при формировании коммуникативной компетенции студентов, в условиях многоязычия, следует учитывать региональные и личностные особенности.

Целью нашего исследования является выявление взаимосвязанных факторов, в совокупности представляющих собой педагогические условия, которые способствуют успешному формированию иноязычной 
коммуникативной компетенции студентов-билингвов технического вуза.

Анализ понятия «коммуникативная компетенция», позволил нам выделить наиболее содержательное его определение: «способность передавать мысли и обмениваться ими в различных ситуациях в процессе взаимодействия с другими участниками общения, правильно использовать систему языковых и речевых норм и выбирать коммуникативное поведение, адекватное аутентичной ситуации общения» [2, с. 29]. Данную компетенцию, которую выделяют как целостный сложный концепт [3] можно назвать ведущей, так как она лежит в основе других компетенций: информационной, социокультурной, социально-политической, а также готовности к образованию и саморазвитию [4, с. 52]. Для формирования данной компетенции исследователи предлагают следующие современные технологии обучения: учебные ресурсы в Интернете, различные мультимедийные образовательные программы, образовательные виртуальные туры, выполнение заданий в виде веб-квестов или создание веб-проектов самими учащимися [5], обучение в области исследований и разработки технологий проектирования [6] и т.д.

На формирование иноязычной коммуникативной компетенции у студентов технического вуза немаловажную роль играют коммуникативные качества обучающихся, определяющие готовность к речевым контактам с другими людьми в межэтническом и межкультурном отношениях. Данные качества диагностируются посредством психологических исследований. В данной работе мы определили уровни коммуникативной подготовки студентов-билингвов МПТИ (ф) СВФУ, посредством методики И.А. Мартьяновой [8]. Общее количество респондентов психологического тестирования составило 86 человек.

Анализ результатов тестирования показал, что у большинства опрошенных студентов (53\%) наблюдается средний уровень коммуникативной подготовки. Данный уровень включает в себя как общительных, готовых к установлению партнерских отношений студентов, так и имеющих множество барьеров в попытке изложения своих мыслей, в том числе этнокультурного характера.

Следующий уровень - средний с тенденцией к низкому выявлен у $27 \%$ респондентов. Представители данного уровня с одной стороны склонны к благоприятной и эффективной коммуникации с деловыми партнерами, но, с другой стороны, не умеют их реализовывать.

$16 \%$ респондентов оказались на среднем уровне коммуникативной подготовки с тенденцией к высокому. Характерными чертами данного уровня являются: доброжелательность, общительность, готовность к установлению контактов, способность работать в команде, толерантность, умения вступать в межнациональную и этнокультурную коммуникации. Тем не менее, у студентов данной группы наблюдаются: отсутствие эмоционального контроля, недостаточное владение вербальными и невербальными средствами общения, которые препятствуют в изложении своей точки зрения по тому или иному вопросу [9, С. 1-9].

Низкий уровень коммуникативной подготовки наблюдается у 2,5\% опрошенных. Следует отметить, что студентам данной группы сложно ориентироваться в обществе, они испытывают трудности в командной работе, не готовы к сотрудничеству, у них отсутствует контроль над своим эмоциональным состоянием. Автор методики психологического тестирования рекомендует провести целенаправленную работу с такими студентами на преодоление существующих этнических, культурных и социальных барьеров [8].

Лишь 1,5\% из опрошенных имеют высокий уровень коммуникативной подготовки. Данный уровень характеризуется способностью легко находить общий язык с другими людьми, используя вербальные и невербальные средства общения, а также готовностью к межэтническим и межкультурным контактам.

Итак, в результате проведенного психологического исследования студентов-билингвов технического вуза мы выявили, что основная часть респондентов готова к эффективной коммуникации, но реализация которой может быть заторможено из-за существующего комплекса коммуникативных проблем.

Исходя из вышеизложенных результатов исследования, следует, что необходимо обратить внимание на дальнейшую целенаправленную комплексную работу по формированию и развитию коммуникативной способности студентов-билингвов технических вузов посредством создания определенных педагогических условий.

Педагогические условия рассматриваются разными исследователями как: создание инновационно-творческой среды; выработка субъектной позиции личности; укрепление практической деятельности; организация рефлексии и саморефлексии; использование вычислительных, информационных и телекоммуникационных технологий и систем; эффективное управление учебной, научной и профессиональной деятельностью студентов [11], а также условия, которые активизируют умственную деятельность, способствуя развитию познавательной самостоятельности при изучении определенного предмета [12]. 
Под педагогическими условиями в формировании коммуникативной компетенции студентов-билингвов, мы понимаем следующий комплекс взаимосвязанных факторов, соответствующих целям, задачам, содержанию, формам и методам обучения иностранному языку в вузе:

1. организация учебного процесса, направленного на повышение уровня мотивационной готовности студентов;

2. учет личностных и этнических особенностей студентов-билингвов в преподавании иностранного языка;

3. использование в процессе обучения современных педагогических технологий, обеспечивающих саморазвитие личности студента;

Далее более подробно охарактеризуем вышеперечисленные факторы.

\section{1. Организация учебного прочесса, направленного на повышение уровня мотивашионной готовности сту $А$ ентов.}

Мотивационные ориентации студентов играют первостепенную роль при обучении профессионально-ориентированному английскому языку технических специальностей. Необходимость усиления мотивационных аспектов при изучении языка рассматривается в работах отечественных (Л.И. Божович, П.Я. Гальперин, А.Н. Леонтьев, А.К. Макарова, П.М. Якобсон) и зарубежных исследователей (Дж. Брунер, Д.Е. Берлайн, Й. Лингарт и других).

Мотивация - это процесс, побуждающий к действию, ориентирующий на активную и продуктивную деятельность студентов, поэтому так важно формирование познавательной мотивации к обучению иностранному языку в техническом вузе. Теоретический анализ психолого-педагогической литературы на тему исследования преобладающей мотивации у студентов технических специальностей при изучении английского языка показал, что существует прямая связь между успешностью учебной деятельности и выявленными мотивационными ориентациями студентов (чем выше мотивация обучающихся, тем плодотворней будет изучение иностранного языка).

Согласно проведенным отечественным и зарубежным исследованиям наибольшей побудительной силой обладает внутренняя мотивация, исходящая непосредственно из деятельности студентов, поэтому при обучении иностранному языку, усилия преподавателя должны быть направлены на формирование и развитие данного вида мотивации.
Для повышения мотивационной ориентированности студентов на изучение иностранного языка, необходимо применять следующие психологические и методические приёмы:

1. Вовлечение эмоциональной сферы в процесс обучения. Создание на занятиях ситуации успеха. Применение на занятиях интересных книг, фильмов на иностранном языке является положительным эмоциональным фактором, способствующим более легкому и прочному запоминанию иностранных слов, грамматики. Еще одним из наиболее мощных способов воздействия на эмоции и чувства учащихся является музыка. Песни способствуют более успешному усвоению грамматических конструкций, совершенствованию навыков произношения, при этом музыка дает возможность снять напряжение, расслабиться и восстановить работоспособность в середине или конце занятия.

2. Использование творческих способностей при обучении, привлечение студентов к участию в различных мероприятия - олимпиадах, конкурсах, викторинах, научно-практических конференциях.

3. Повышение мотивационной ориентированности студентов через социокультурный и страноведческий компонент содержания обучения. В образовательных программах по иностранному языку отмечается тесная связь коммуникативной компетенции с социокультурными и страноведческими знаниями, которые также способствуют повышению мотивации студентов обучению иностранному языку. Общеизвестно, что культура оказывает непосредственное влияние на формирование личности человека. Социокультурный аспект обучения иностранному языку обеспечивает включение студентов в диалог культур, знакомство с достижениями национальной культуры, а также формированию толерантного отношения к традициям и обычаям народа изучаемого языка. Лингвострановедческий компонент заключается в фиксации страноведческих сведений в единицах языка и способствует обогащению предметносодержательного плана. На наш взгляд, именно лингвострановедение может стать опорой для повышения мотивационной ориентированности студентов на изучение иностранному языку, так как, во-первых, осуществляет непосредственно обучение языку и, во-вторых, даёт сведения о стране изучаемого языка.

4. Повышение мотивации обучающихся к изучению иностранного языка с помощью различных педагогических и информационных технологий.

5. Встречи, дискуссии с носителями языка и посещение их страны - может служить одним из сильнейших стимулов, повышающих интерес студен- 
тов к изучению иностранного языка.

6. При проведении занятий необходимо акцентировать внимание студентов на непосредственную сферу применения полученных знаний, «связь теории с жизнью» повышает интерес и внимание студентов.

7. Весь образовательный процесс должен строиться на принципах личностно-ориентированного подхода, в котором личность обучающегося является высшей ценностью общества.

Для повышения мотивационной ориентированности студентов на изучение иностранного языка, авторы предлагают применять следующие психологические и методические приёмы: 1) вовлечение эмоциональной сферы в процесс обучения; 2) использование творческих способностей; 3) опора на социокультурный и страноведческий компоненты содержания обучения; 4) встречи, дискуссии с носителями языка и посещение их страны; 5) «связь теории с жизнью»; 6) использование принципов личностно-ориентированного подхода

\section{2. Учет ^ичностных и этнических особенностей студентов в преподавании иностранного языка.}

Знание и учет личностных особенностей студента черт характера, темперамента, способностей, общего интеллектуального развития, интересов, мотивов, работоспособности и т.д., -позволяет эффективно организовывать учебный процесс.

При обучении иностранному языку, помимо личностных особенностей студента, следует учитывать этнический компонент, влияющий на усвоение иноязычного материала.

В случаях, когда овладение иностранным языком студентами-билингвами (например, якутско-русскими) осуществляется в условиях при ограниченном количестве академических часов и, соответственно, при небольшой речевой практике, происходящей исключительно на уроках иностранного языка, возникают определенные сложности. В связи с этим, преподавателям иностранного языка необходимо применять и усовершенствовать новые методы и технологии обучения студентовбилингвов, ориентированные на учет лингвистических особенностей терминологической системы и научнотехнического стиля трех языков (якутского, русского, английского), специфики проявления явлений переноса и интерференции в условиях овладения специальной лексикой, механизмы переключения с одного языкового кода на другой, особенностей концептуальной репрезентации лексических систем трех языков в сознании студентов.
В результате реализации данного фактора одним из авторов работы составлен электронный учебный англорусско-якутский терминологически словарь тезаурусного типа для студентов технического вуза. Трехъязычный словарь является эффективным средством обучения иноязычной профессиональной коммуникации, так как включает в себя части (глоссарий, англо-русско-якутский словарь) с определением (объяснением путем ассоциаций) того или иного термина на родном языке студентов. Ассоциации к сложным терминам с уже знакомыми для студента-билингва предметами, способствуют легкому запоминаю и правильному употреблению терминов в контексте профессиональной коммуникации.

\section{3. Использование в прошессе обучения современных педагогических технологий, обеспечиваюших саморазвитие личности студента.}

Реализация данного фактора будет успешной, если использовать в обучении личностно-ориентированные методы, направленные непосредственно на индивидуальность каждого обучающегося, актуализирующие его активную деятельность на получение новых знаний, умений, профессиональных навыков и способностей находить творческие подходы к решению различных профессиональных задач. Среди таких методов мы выделили:

1. Коммуникативный метод, в результате использования которого, основные языковые навыки равномерно развиваются в процессе живого общения.

2. Метод проектов, опирающийся на концепцию развивающего обучения, суть которого состоит в повышении интеллектуального потенциала обучающегося путем активизации процесса развития интеллектуальных качеств будущих специалистов и совершенствования их стиля мыслительной творческой деятельности в процессе профессиональной подготовки.

3. Обучение в сотрудничестве, направленное на социализацию, развитие интеллектуальных, духовных и физических способностей личности в коллективе, взаимооценку, а также на формирование коммуникативных умений.

4. Применение новых информационных коммуникативных технологий в преподавании иностранного языка, которые позволяют разнообразить формы работы и сделать учебный процесс интересным и запоминающимся для студентов.

В применении вышеуказанных методов и технологий обучения важную роль играет материально-техническая база образовательного учреждения. В нашем случае в МПТИ (ф) СВФУ функционируют четыре лингафонных 
кабинета, оснащенные современными компьютерными средствами и информационными системами. Также имеется «Центр открытого доступа» с современной переговорной комнатой с полным комплектом для реализации дистанционного образования. На базе кафедры английской филологии реализуется Лингвистический центр, целью которого является повышение языковой компетентности студентов и преподавателей института. Результатом работы центра является успешная академическая мобильность студентов.

Таким образом, решение проблемы эффективного формирования коммуникативной компетенции двуязычных студентов в процессе обучения профессиональному иностранному языку требует целенаправленного, последовательного, комплексного подхода к созданию и реализации вышеуказанного комплекса факторов, которые в первую очередь направлены на:

- повышение мотивации при изучении иностранного языка;

- преодоление социальных, этнических и культурных барьеров на пути обучения;

- организацию учебного процесса с использованием современных методов и технологий обучения.

\section{ЛИТЕРАТУРА}

1. ФГОС В0 (3++) по направлению подготовки 21.03.01 Нефтегазовое дело [Электронный ресурс] - Режим доступа: http://fgosvo.ru/ - (Дата обращения: 31.01.2019).

2. Колесникова И.Л., Долгина 0.А. Англо-русский терминологический справочник по методике преподавания иностранных языков. СПб.: Русско-Балтийский информационный центр «Блиц»; CambridgeUniversityPress, 2001. 224 с.

3. Kucherenko I., Mamchur L., Mamchur Y. Technological Principles of the Formation of a Pupil's Communicative Competence. Revista Romaneasca Pentru Educatie Multidimensionala, 2020, V. 12, I. 1, pp. 126-146

4. Соловова Е.Н. Задачи языкового образования в русле глобальных реформ // Первое сентября. 2005. №17. С. 49-54.

5. Shvets T.A. Use of Modern Informational Technologies in the Process of Students' Communicative Competence Formation. Psycholinguistics, 2015, V. 17 pp. $239-249$

6. Bissenbayeva Zh., Aurenova M., AubakirovaZh. Modern technologies of communicative competence formation. 5th World Conference on Educational Sciences. Procedia Social and Behavioral Sciences, 2014, V. 116, pp. 4780-4784.

7. Шагдарова Т.В., Маланов И.А. Диагностика коммуникативной компетентности студентов технического вуза Республики Саха (Якутия) // Учёные записки Забайкальского государственного университета. 2019. Т. 14, № 4. С. 76-84.

8. Мартьянова И.А. Диагностика уровня сформированности коммуникативной компетентности студентов вуза в условиях поликультурного общества [Электронный ресурс] // Novalnfo. 2016. №46-2. С. 1-9. Точка доступа: https://novainfo.ru/pdf/046-2 (дата обращения: 25.03.2019).

9. Лысуенко С.А., Власкина И.В. Диагностика коммуникативной компетентности как профессионально важного качества медицинских сестер психиатрического профиля // Педагогическое образование в России. 2015. №3. С. 48-52.

10. Рыбкина А.А. Педагогические условия формирования профессиональных умений курсантов учебных заведений МВД в процессе обучения иностранному языку / А.А. Рыбкина. - Саратов : Саратов. юрид. ин-т МВД России, 2005. - 152 с.

11. Орехова Ю.Ю., Гребенкина Л.К., Суворова Н.А., Ставрук М.А. Педагогические условия формирования профессиональной компетентности студентов технического университета. PERIODICO TCHE QUIMICA, 2020, Том. 17., Вып. 34., С. 291-302.

12. Ivanova A.V., Golikov A.I., Skryabina A.G. Pedagogical Conditions for the Development of Cognitive Independence for Humanitarian Studies in the Process of Mathematical Education. REVISTA GENERO \& DIREITO, 2020, V. 9, I. 2, pp. 667-685

13. Симонова Н.М. Опыт исследования характера мотивации (на матер, студ. исследований) В кн.: Иностранный язык в высшей школе. Вып. 15. М., 1980. C. 81-87.

( З Заровняева Сильвия Сергеевна (silka86@mail.ru), Шагдарова Туяна Владимировна (tuyanash.21@mail.ru), Маланов Иннокентий Александрович (malanov52@mail.ru).

Журнал «Современная наука: актуальные проблемы теории и практики» 